Biol. Stud. 2021; 15(3): 41-50 • DOI: https://doi.org/10.30970/sbi.1503.663

www.http://publications.Inu.edu.ua/journals/index.php/biology

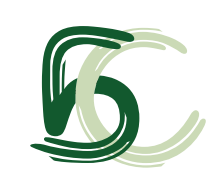

UDC: $573.3: 577.29: 616.8-092$

\title{
CONSTRUCTION OF MODEL STRAIN OF YEAST \\ SACCHAROMYCES CEREVISIAE WITH REGULATED EXPRESSION OF RECOMBINANT HUMAN ALPHA-SYNUCLEIN
}

\author{
N. V. Hrushanyk ${ }^{1}$, Y. I. Fedorko ${ }^{1}$, O. V. Stasyk $\oplus^{2}$, O. G. Stasyk $\bigotimes^{1,2}$ \\ ${ }_{1}^{1}$ Ivan Franko National University of Lviv, 4 Hrushevskyi St., Lviv 79005, Ukraine \\ ${ }^{2}$ Institute of Cell Biology, NAS of Ukraine, 14-16 Drahomanov St., Lviv 79005, Ukraine
}

Hrushanyk, N.V., Fedorko, Y.I., Stasyk, O.V., \& Stasyk, O.G. (2021). Construction of model strain of yeast Saccharomyces cerevisiae with regulated expression of recombinant human alphasynuclein. Studia Biologica, 15(3): 41-50 • DOI: https://doi.org/10.30970/sbi.1503.663

Background. Improper folding and accumulation of $\alpha$-synuclein aggregates are among the causes of Parkinson's disease. The most important factor influencing the process of $\alpha$-synuclein aggregation is the level of this protein in neurons which depends on the balance between its synthesis, degradation and secretion. Under certain conditions, when $\alpha$-synuclein is synthesized at a high level, monomers of this protein can aggregate on the lipid membrane, which leads to the formation of amyloids, fibrils and protofibrils unable to perform their physiological functions. Since it is virtually impossible to study the properties of $\alpha$-synuclein in vivo, researchers are actively using model biological systems (single-celled microorganisms, human cell lines, animal models etc.).

The aim of this study was to construct a recombinant strain of Saccharomyces cerevisiae with controlled expression of human $\alpha$-synuclein to study the regulation and properties of this protein and for screening for new low molecular weight chemical compounds which can induce $\alpha$-synuclein aggregation and/or degradation.

Materials and Methods. A recombinant strain of S. cerevisiae with controlled expression of $\alpha$-synuclein conjugated to a green fluorescent protein was isolated. Western blotting with specific anti- $\alpha$-synuclein antibodies was used to detect recombinant $\alpha$-synuclein in yeast cells. Intracellular localization of heterologous chimeric green fluorescent protein conjugated to $\alpha$-synuclein was also examined by fluorescence microscopy.

Results. To construct a recombinant strain of $S$. cerevisiae, the coding sequence of the human wild-type $\alpha$-synuclein gene was expressed under the regulated promoter

() 2021 N. V. Hrushanyk et al. Published by the Ivan Franko National University of Lviv on behalf of Біологічні Студії / Studia Biologica. This is an Open Access article distributed under the terms of the Creative Commons Attribution 4.0 License which permits unrestricted reuse, distribution, and reproduction in any medium, provided the original work is properly cited.

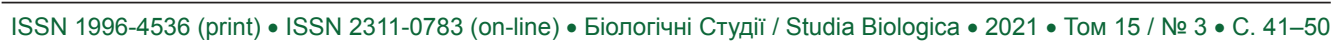


of the ScMET25 gene. Analysis of the effect of different concentrations of exogenous methionine as a factor regulating the expression of the ScMET25 promoter on the content of recombinant protein showed that the expression of the human $\alpha$-synuclein gene in $S$. cerevisiae is repressed in the presence of methionine at a concentration of $10 \mathrm{mg} / \mathrm{L}$ and higher. During long-term cultivation of yeast cells, this effect decreased due to the depletion of methionine in the growth medium. As a result, recombinant protein synthesis was restored, and $\alpha$-synuclein content in such cells approached that of cells grown in a medium with a low concentration of $(5 \mathrm{mg} / \mathrm{L})$, or without methionine. It was also found that overproduction of recombinant $\alpha$-synuclein in $S$. cerevisiae cells had virtually no effect on culture growth, indicating the absence or a very weak toxic effect of human $\alpha$-synuclein on yeast physiology.

Conclusions. The obtained data indicate a concentration-dependent effect of methionine on the level of recombinant $\alpha$-synuclein synthesis in $S$. cerevisiae yeast cells. Such controlled expression of the studied protein can be used to screen for compounds capable of promoting dose-dependent aggregation or degradation of $\alpha$-synuclein in yeast cells and potentially in human cells as well.

Keywords: Saccharomyces cerevisiae, $\alpha$-synuclein, regulated expression

Registration number and Funding source. \# 0117U001226, Grant "Investigation of the mechanisms of autophagic degradation of abnormal forms of human $\alpha$-synuclein induced by low-molecular compounds in the model biosystems" and \# 0115U004200, Grant "Modeling in the yeast cells of molecular processes of Parkinson's disease and analysis of the influence of exo- and endogenous factors on the aggregation and degradation of human $\alpha$-synuclein" to Department of Cell Signaling of the Institute of Cell Biology, NAS of Ukraine.

\section{INTRODUCTION}

Today, a great achievement of microbiology, molecular biology, genetics and biochemistry is the possibility of transferring pathological processes, which at the molecular and cellular levels of organization contribute to certain human diseases, into unicellular eukaryotic organisms such as yeasts [4]. The special value of the yeast models lies in its utilization for the study of molecular mechanisms of human neurodegenerative diseases because such pathologies are difficult to model on multicellular systems as methods of their manipulation are painful and directly or indirectly lead to fatal consequences. Therefore, modern researchers rely on artificial models of neurodegenerative diseases and Parkinson's disease (PD) in particular. Interestingly, although distant in evolutionary terms from human, eukaryotic yeasts provide cellular environment and metabolism in many aspects identical to human neurons. Some cellular mechanisms and their features are similar in all eukaryotes, such as membrane transport, protein degradation, mitochondrial dysfunction, oxidative stress, regulation of transcription, and regulation of balance between newly synthesized proteins and proteins that must be degraded [6]. Yeasts are also able to efficiently produce human recombinant proteins [9]. Using molecular biological and cytogenetic methods, scientists thus can identify the causes and describe the pathogenesis of human neurodegenerative diseases such as PD, Alzheimer's disease, Huntington's disease, amyotrophic lateral sclerosis, at the celIular and molecular levels.

ISSN 1996-4536 (print) • ISSN 2311-0783 (on-line) • Біологічні Студії / Studia Biologica • 2021 • Том 15 / № 3 • C. 41-50 
Yeasts as a model of human neurodegenerative pathologies nevertheless have certain limitations, as their cells do not participate in complex intercellular interactions, unlike human neurons. They also do not possess some regulatory pathways that affect the development of multicellular organisms, specific to neurons.

The influence of the expression of several genes, the products of which are known to be involved in the development of PD, was studied in yeast models [11]. In particular, it was shown that the expression of a single copy of $\alpha$-synuclein gene conjugated to green fluorescent protein gene did not affect the growth of the host. However, expression of two copies of the SNCA gene with the A53T mutation caused a marked delay in the growth of cells of the model $S$. cerevisiae strain. With that model, several phenotypic manifestations of PD were also observed which included the affected ubiquitin-proteasomal system and altered lipid metabolism and vesicular transport $[8,11,14]$. Subsequently, this model was used to study the role of autophagy and posttranslational modifications of $\alpha$-synuclein that also contribute to pathogenesis of PD [12]. These findings confirm the important potential of amyloid-producing yeast models in search for new drug compounds and for deciphering the molecular mechanisms underlying their actions [7].

We previously described an $\alpha$-synuclein producing strain of an alternative yeast species, Ogataea (Hansenula) polymorpha [2,10]. However, that recombinant human protein was overall non-toxic in this yeast. Therefore, we aimed herein to construct a recombinant strain of $S$. cerevisiae with controlled expression of human $\alpha$-synuclein as an alternative experimental PD model to screen for new low molecular weight chemical compounds that affect $\alpha$-synuclein aggregation and degradation.

\section{MATERIALS AND METHODS}

Strains, media and microbial techniques. S. cerevisiae strain used in this work was an auxotrophic wild-type strain FY2 (MAT $\alpha$ ura3 $\Delta 0)$ which is a direct descendant of S288C [13]. Yeast cells were cultivated at $30{ }^{\circ} \mathrm{C}$ on standard liquid or solid media: rich medium YPD (1\% yeast extract, $2 \%$ bacto-peptone, $1 \%$ glucose) or synthetic YNB medium (Difco) - $(0.17 \%$ yeast nitrogen base without amino acids, $0.5 \%$ ammonium sulfate). Solid media contained agar at $2 \%$ concentration. The concentration of carbon source (glucose) was $2 \%\left(w \times v^{-1}\right)$, unless indicated otherwise. Methionine was supplemented into the medium at 5-100 mg/L concentration immediately before yeast cultivation started. Cell density was determined by absorbance at $600 \mathrm{~nm}$.

Electrotransformation of the yeast $S$. cerevisiae. The method is based on the ability of yeast cells to absorb exogenous DNA under the influence of an electrical impulse. The culture of $S$. cerevisiae was grown in $300 \mathrm{~mL}$ of liquid YPD medium at $30{ }^{\circ} \mathrm{C}$ to an optical density $\mathrm{OD}_{600}=0.5-1.2\left(1-2 \times 10^{7} \mathrm{cells} / \mathrm{mL}\right)$. The cells were pelleted at $3000 \mathrm{rpm}$ for $10 \mathrm{~min}$ using Eppendorf 5417C Centrifuge, washed twice with sterile double-distilled $\mathrm{H}_{2} \mathrm{O}$ and resuspended in $200 \mu \mathrm{L}$ of $\mathrm{H}_{2} \mathrm{O}$. Then 100-150 ng of plasmid DNA (pKF48-SNCA) (Fig. 1) was added to $100 \mu \mathrm{L}$ of the cell suspension. After that, $250 \mu \mathrm{L}$ of $50 \%$ PEG 4000 was added and mixed thoroughly. The resulting mixture was incubated at $42{ }^{\circ} \mathrm{C}$ for $15 \mathrm{~min}$. After incubation, the mixture was transferred to a sterile $0.2 \mathrm{~cm}$ electroporation cuvette and electroporated at $1.5 \mathrm{kV}, 25 \mu \mathrm{F}, 200 \mathrm{Ohm}$. Immediately after electroporation, the liquid cooled YPD were added to the cells. For selection of transformants, the cells were seeded on plates with a selective medium and incubated for 3-4 days.

ISSN 1996-4536 (print) • ISSN 2311-0783 (on-line) • Біологічні Студії / Studia Biologica • 2021 • Том 15 / № 3 • C. 41-50 
N-terminally GFP-tagged $\alpha$-synuclein detection by fluorescence microscopy. Axio Imager A1 fluorescence microscope (Carl Zeiss Microlmaging, Jena, Germany) and Axio Cam MRm digital camera (Carl Zeiss Microlmaging) were used to obtain fluorescence micrographs of the studied yeast strain. The photos were taken at $600 \times$ magnification. The resulting photos were processed using computer programs AxioVision 4.5 (Carl Zeiss Microlmaging) and Adobe Photoshop CS5 (Adobe Systems, Mountain View, CA).

Yeast cell-free extracts preparation. To prepare cell-free extracts using trichloroacetic acid (TCA), $0.4 \mathrm{ml}$ of $12.5 \%$ TCA was added to the precipitate of cells washed from the culture medium. The resulting cell suspension was kept for $2 \mathrm{~h}$ at $-70{ }^{\circ} \mathrm{C}$ and precipitated by centrifugation for $3 \mathrm{~min}$ at $14000 \mathrm{rpm}$. The precipitate was washed twice with $0.5 \mathrm{ml}$ of $80 \%$ acetone solution cooled to $-20{ }^{\circ} \mathrm{C}$ and then dried at room temperature and resuspended in $0.1 \mathrm{ml}$ of lysis buffer ( $1 \% \mathrm{SDS}+0.1 \mathrm{M} \mathrm{NaOH})$. An equal volume of double Laemmli buffer (62.5 mM Tris-HCl (pH 6.8), 1 mM EDTA, $2 \%$ SDS, $5 \%$ $\beta$-mercaptoethanol, $10 \%$ glycerol, $0.4 \%$ bromophenol blue) was added to the obtained lysate. The strain biomass taken for Western blot analysis from media with different concentrations of methionine was the same for all time points.

Protein SDS-PAGE and immunoblot analysis. For electrophoretic separation of proteins, cell-free extracts were heated at $95^{\circ} \mathrm{C}$ for $10 \mathrm{~min}$ in Laemmli buffer for samples. Protein electrophoresis was performed in $8 \%$ SDS page in the presence of SDS in the Laemmli buffer system. Transfer of proteins from SDS-PAGE to polyvinylide fluoride (PVDF) was performed for $2 \mathrm{~h}$ at the strength of the electric current of $250 \mathrm{~mA}$ in a buffer containing: $25 \mathrm{mM}$ Tris- $\mathrm{HCl}, \mathrm{pH} 8.3,192 \mathrm{mM}$ glycine, $20 \%$ methanol. Free centers of binding antibodies on the membrane were blocked for $1 \mathrm{~h}$ with $5 \%$ skim milk in PBS-T (140 mM NaCl, $2.7 \mathrm{mM} \mathrm{KCl}, 10 \mathrm{mM} \mathrm{Na}_{2} \mathrm{HPO}_{4}, 1.8 \mathrm{mM} \mathrm{KH}_{2} \mathrm{PO}_{4}, 0.1 \%$ Tween-20). Subsequently, the membrane was incubated with mouse primary anti- $\alpha$-synuclein antibodies in blocking buffer (1:2500 dilution) overnight, followed by washing with blocking buffer 3 times for 10-15 min. Anti-mouse IgG conjugated to horseradish peroxidase at a 1:10,000 dilution in blocking buffer were used as secondary antibodies. Incubation with secondary antibodies was performed for 2-4 h, after which the membrane was washed with PBS-T 5 times for 10-15 minutes. Immunoreactive bands on blots were detected by ECL (solution I: $100 \mathrm{mM}$ Tris- $\mathrm{HCl}$ ( $\mathrm{pH} 8.5$ ), 4.4\% luminol, $1.5 \mathrm{n}$-coumaric acid, solution II: $100 \mathrm{mM}$ Tris- $\mathrm{HCl}(\mathrm{pH} 8.5), 30 \% \mathrm{H}_{2} \mathrm{O}_{2}$, solutions I and II were mixed in a ratio of $1: 1$ immediately before use). The exposure time of the treated membranes on X-ray film depended on the intensity of chemiluminescence and ranged from 1 to $15 \mathrm{~min}$. The films were developed in a standard phenidone-hydroquinone developer and fixed with acid fixation.

Statistical Analysis. Statistical analysis of the results was performed using Microsoft Excel 2016. The calculation of the main statistical indicators was performed on the basis of the direct quantitative data (arithmetic mean value - M; arithmetic mean standard error $-m$ ). To assess the probability of the difference between the statistical characteristics of the three alternative data sets (data of three independent experiments), the Student's ratio was calculated. The difference in the indications of probability $p \geq 0.95$ (significance level) was considered probable at $P<0.05$ after calculating $t$ according to the table of Student's $t$-distribution.

ISSN 1996-4536 (print) • ISSN 2311-0783 (on-line) • Біологічні Студії / Studia Biologica • 2021 • Том 15 / № 3 • C. 41-50 


\section{RESULTS AND DISCUSSION}

Studies indicate that one of the main reasons for the development of PD is the dysfunction of $\alpha$-synuclein protein, which in the case of pathology is the main component of abnormal inclusions in dopaminergic neurons of the substantia nigra - Levy's body [1].

Since in our previous studies $[2,10]$ we failed to obtain model strains of $O$. polymorpha in which $\alpha$-synuclein would form potentially cytotoxic aggregates, we constructed a model strain with regulated expression of the wild-type SNCA gene in S. cerevisiae.

To simulate the PD-like process in $S$. cerevisiae cells, we used a pre-engineered vector pKF48-SNCA [2], which contained a cassette of expression of the chimeric protein SNCA-GFP, under a promoter whose activity is negatively regulated by methionine content in the culture medium. The cassette consisted of the coding sequence of the human wild-type $\alpha$-synuclein (SNCA) gene conjugated to the green fluorescent protein (yEGFP) gene (Fig. 1). This chimeric construct is useful for studying the processes of $\alpha$-synuclein aggregation and degradation, as well as for monitoring intracellular localization by fluorescence microscopy. The vector contains a $6 \times$ His-tag sequence, which allows detecting the chimeric protein by Western blot analysis and isolating it from cell lysates via affinity chromatography. The vector also contains the selective URA3 marker for $S$. cerevisiae and the ampicillin resistance gene $\left(\mathrm{Amp}^{\mathrm{R}}\right)$ for the selection of Escherichia coli transformants.

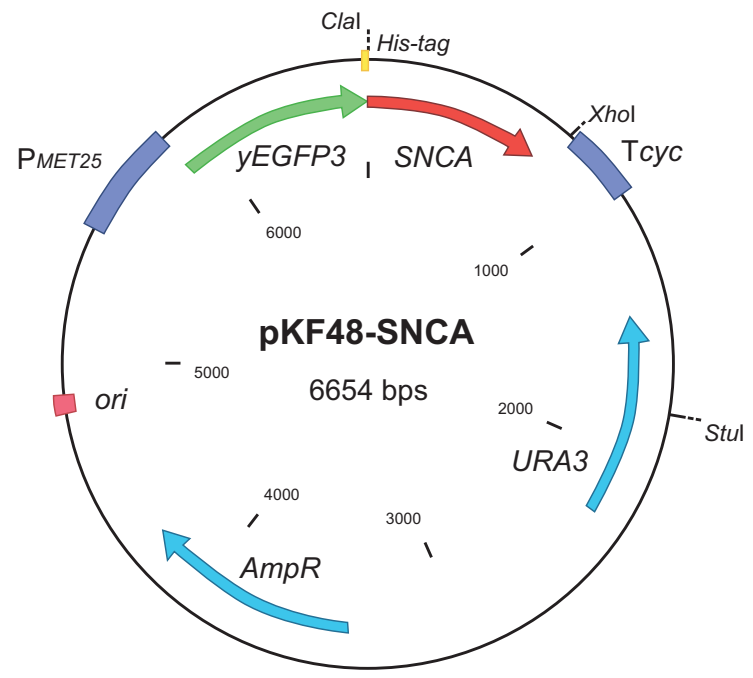

Fig. 1. Scheme of the vector pKF48-SNCA for expression of the chimeric construct SNCA-EGFP [2]

Рис. 1. Схема вектора pKF48-SNCA для експресії химерного конструкту SNCA-EGFP [2]

Selection of $S$. cerevisiae transformants was performed on a minimal mineral medium without the addition of uracil but at the presence of methionine in the concentration of $50 \mathrm{mg} / \mathrm{L}$ for repression of $P_{M E T 25}$ from which SNCA-EGFP fused genes are expressed. The presence of a chimeric form of GFP-conjugated $\alpha$-synuclein in the cells of the model strain was confirmed by fluorescence microscopy (Fig. 2).

Microscopic analysis of all obtained individual transformants did not reveal apparent aggregates of GFP-tagged $\alpha$-synuclein. Instead, a uniform cytosolic localization of the soluble chimeric protein, which was most likely in the form of oligomers, was well 
visible (Fig. 2). Since the death of dopaminergic neurons of the substantia nigra in the case of PD occurs under conditions of an increased synthesis of $\alpha$-synuclein, for further work we selected a strain characterized by a higher fluorescence signal intensity visualized by microscopy.

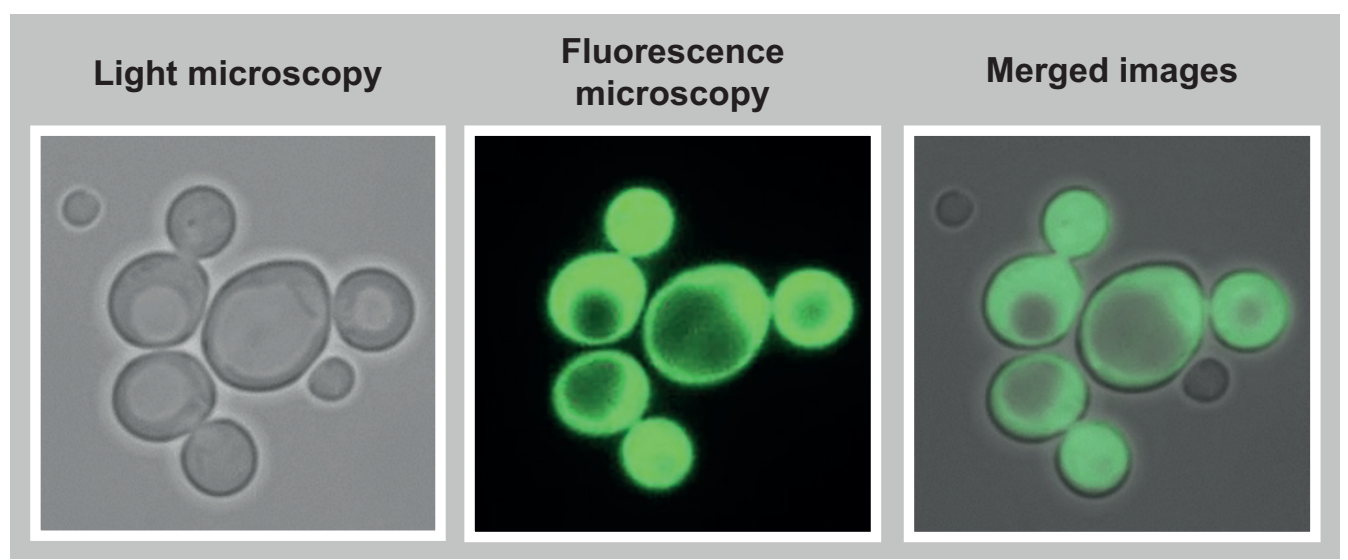

Fig. 2. Fluorescent microphotography of $S$. cerevisiae strain producing GFP-tagged human $\alpha$-synuclein. Cells were grown on the medium containing $2 \%$ glucose as carbon source

Рис. 2. Флуоресцентні мікрофотографії штаму S. cerevisiae, що продукує $\alpha$-синуклеїн людини, мічений GFP. Клітини вирощували на середовищі, що містить $2 \%$ глюкози як джерело карбону

The presence of heterologous $\alpha$-synuclein-GFP chimera of the predicted size in the cells of the model strain was also confirmed by Western blot analysis (Fig. 3). To do this, the cells of the model strain, pre-cultured on a rich nutrient medium YPD, were transferred into a mineral medium with the addition of methionine at concentrations of 5,10 , 20,30 and $50 \mathrm{mg} / \mathrm{L}$. Because the chimeric SNCA-GFP construct is controlled by the methionine-repressed $P_{\text {MET25 }}$ promoter, $\alpha$-synuclein levels in the cells of the model strain differed at different exogenous concentrations of methionine.

Using antibodies to $\alpha$-synuclein, we found that after $5 \mathrm{~h}$ of culturing $S$. cerevisiae cells on the medium with methionine at its concentrations of $10,20,30$ and $50 \mathrm{mg} / \mathrm{L}$ $\alpha$-synuclein levels were negligible. Under $5 \mathrm{mg} / \mathrm{L}$ of methionine in the growth medium, or its absence, there was an active synthesis of recombinant protein. At the depletion of methionine in the nutrient medium after $15 \mathrm{~h}$ of recombinant yeast strain cultivation, synthesis of $\alpha$-synuclein was restored, as evidenced by the results of Western blot analysis (Fig. 3), most probably due to the exhaustion of methionine from the medium.

As mentioned above, modeling of molecular processes involved in the development of PD in yeasts was first performed on S. cerevisiae. In this system, it was first found that, depending on the genotype of the strains expressing the SNCA gene, $\alpha$-synuclein could have a negative or neutral effect on the growth of the host strain [3]. In view of this, we analyzed the growth kinetics of the $S$. cerevisiae strain that expresses heterologous human $\alpha$-synuclein on a mineral medium with the addition of $2 \%$ glucose as a carbon source in the absence of methionine or with the addition of this amino acid in excess (100 mg/L) to inhibit the expression of $\alpha$-synuclein (Fig. 4). As a control strain we used S. cerevisiae wild type strain (FY2) grown on a mineral medium containing $2 \%$ glucose at the presence or without methionine. Growth kinetics of the wild type strain was similar to that of the model strain (data is not shown).

ISSN 1996-4536 (print) • ISSN 2311-0783 (on-line) • Біологічні Студії / Studia Biologica • 2021 • Том 15 / № 3 • C. 41-50 


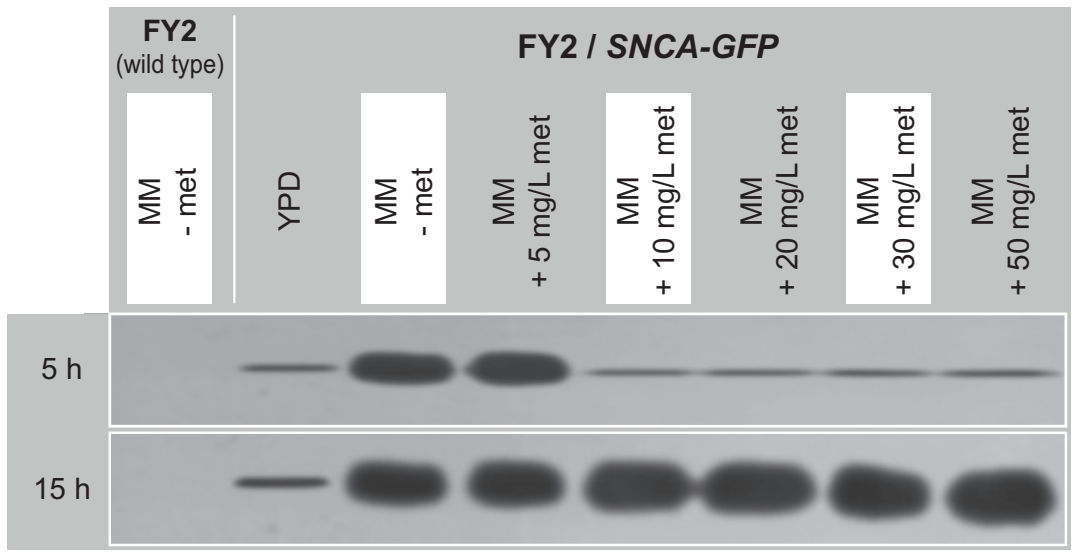

Fig. 3. Western blot detection of $\alpha$-synuclein in cells of the model yeast $S$. cerevisiae strain, cultured on rich medium (YP $+2 \% \mathrm{Glc})$, as well as on mineral medium (MM) without (-met) or with different concentrations (5-50 mg/L) of methionine. The duration of yeast cultivation -5 and $15 \mathrm{~h}$

Рис. 3. Вестерн-блот детекція $\alpha$-синуклеїну в клітинах модельного штаму дріжджів S. cerevisiae, культивованих на багатому середовищі (YP + $2 \%$ Glc), а також на мінеральному середовищі (MC) без метіоніну (-met) або з різними концентраціями (5-50 мг/л) метіоніну. Тривалість вирощування біомаси дріжджів становила 5 і 15 год

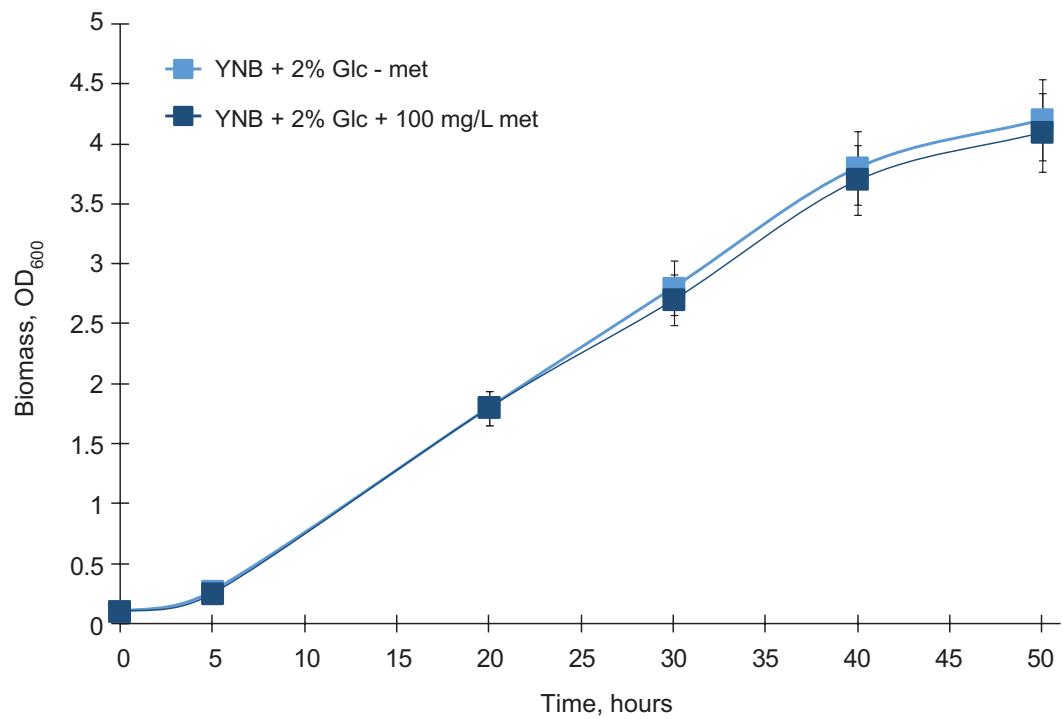

Fig. 4. Growth kinetics of the model yeast $S$. cerevisiae strain on the medium with excess of methionine (YNB $+2 \% \mathrm{Glc}+100 \mathrm{mg} / \mathrm{L}$ met) and without amino acid (YNB $+2 \% \mathrm{Glc}-\mathrm{met})$

Рис. 4. Кінетика росту модельного штаму дріжджів S. cerevisiae на середовищі з надлишком метіоніну (YNB + 2\% Glc + $100 \mathrm{mg} / \mathrm{L} \mathrm{met)} \mathrm{та} \mathrm{без} \mathrm{амінокислоти} \mathrm{(YNB} \mathrm{+} \mathrm{2 \%} \mathrm{Glc} \mathrm{-} \mathrm{met)}$

It was found that the expression of the gene encoding $\alpha$-synuclein apparently did not affect the growth of $S$. cerevisiae model strain or its viability. Despite the lack of cytotoxic effects of $\alpha$-synuclein, we propose that this strain can be used to screen for mutations and chemical compounds that may increase the degree of aggregation of this human protein, or accelerate its degradation. 


\section{CONCLUSIONS}

We constructed a novel model strain of the baker's yeast $S$. cerevisiae expressing recombinant human $\alpha$-synuclein and demonstrated that, contrary to 0 . polymorpha counterpart produced with the same vector $[2,10]$, in S. cerevisiae expression from the control of promoter of the MET25 biosynthetic gene is readily regulated by exogenous methionine. This effect decreased with the prolonged time of incubation and was accompanied by the resumption of recombinant protein biosynthesis. However, observed no apparent cytotoxic effect of the recombinant protein on its host at its highest level of expression. At the same time, the foreign protein did not form intracellular aggregates and exhibit uniform cytosolic localization. We propose that a version of $\alpha$-synuclein carrying mutation A53T that renders it prone to aggregation [5] has to be compared with the current wild-type protein form. Alternatively, the developed S. cerevisiae strain can be used in further studies on screening intra- and extracellular factors which can induce $\alpha$-synuclein aggregation or degradation.

\section{FUNDING}

The experiments described in this article were partially supported by the project of the Department of Biochemistry, Faculty of Biology, Ivan Franko National University of Lviv "Investigation of the mechanisms of autophagic degradation of abnormal forms of human $\alpha$-synuclein induced by low-molecular compounds in the model biosystems" (\# 0117U001226) and by the grant "Modeling in yeast cells of the molecular processes of Parkinson's disease and analysis of the effect of exo- and endogenous factors on the processes of aggregation and degradation of human $\alpha$-synuclein" of the Department of Cell Signaling of the Institute of Cell Biology, NAS of Ukraine (\# 0115U004200).

\section{COMPLIANCE WITH ETHICAL STANDARDS}

Conflict of Interest: The authors declare that the research was conducted in the absence of any commercial or financial relationships that could be construed as a potential conflict of interest.

Animal Rights: This article does not contain any studies with animal subjects performed by any of the authors.

\section{AUTHOR CONTRIBUTIONS}

Conceptualization, [O.G.S., O.V.S.]; methodology, [O.G.S., N.V.G., Y.I.F.]; validation, [O.G.S., O.V.S.]; formal analysis, [O.G.S., O.V.S., N.V.G., Y.I.F.].; investigation, [O.G.S., O.V.S., N.V.G., Y.I.F.]; resources, [O.G.S., O.V.S., N.V.G., Y.I.F.]; data curation, [O.G.S., O.V.S.]; writing - original draft preparation, [O.G.S.]; writing - review and editing, [O.V.S.]; visualization, [N.V.G., Y.I.F.] supervision, [O.G.S., O.V.S.]; project administration, [O.G.S., O.V.S.]; funding acquisition, [O.G.S., O.V.S.].

All authors have read and agreed to the published version of the manuscript.

1. Clayton, D.F., \& George, J.M. (1998). The synucleins: a family of proteins involved in synaptic function, plasticity, neurodegeneration and disease. Trends in Neurosciences, 21(6), 249-254. Crossref • Google Scholar 
2. Denega, I.O., Klymyshyn, N.I., Sybirna, N.O., Stasyk, O.V., \& Stasyk, O.G. (2014). Modeling of molecular processes underlying Parkinson's disease in cells of methylotrophic yeast Hansenula polymorpha. Studia Biologica, 8(2), 5-16.

Crossref $\bullet$ Google Scholar

3. Franssens, V., Boelen, E., Anandhakumar, J., Vanhelmont, T., Büttner, S., \& Winderickx, J. (2010). Yeast unfolds the road map toward a-synuclein-induced cell death. Cell Death and Differentiation, 17(5), 746-753.

Crossref $\bullet$ PubMed $\bullet$ Google Scholar

4. Gitler, A.D. (2007). Beer and bread to brains and beyond: can yeast cells teach us about neurodegenerative disease? Neurosignals, 16(1), 52-62.

Crossref $\bullet$ PubMed $\bullet$ Google Scholar

5. Lashuel, H.A., Petre, B.M., Wall, J., Simon, M., Nowak, R.J., Walz, T., \& Lansbury, P.T. (2002). a-Synuclein, especially the Parkinson's disease-associated mutants, forms pore-like annular and tubular protofibrils. Journal of Molecular Biology, 322(5), 1089-1102.

Crossref • Google Scholar

6. Mohammadi, S., Saberidokht, B., Subramaniam, S., \& Grama, A. (2015). Scope and limitations of yeast as a model organism for studying human tissue-specific pathways. BMC Systems Biology, 9(1).

Crossref $\bullet$ PubMed $\bullet$ PMC $\bullet$ Google Scholar

7. Rencus-Lazar, S., DeRowe, Y., Adsi, H., Gazit, E., \& Laor, D. (2019). Yeast models for the study of amyloid-associated disorders and development of future therapy. Frontiers in Molecular Biosciences, 6, 15.

Crossref $\bullet$ PubMed $\bullet$ PMC $\bullet$ Google Scholar

8. Soper, J.H., Roy, S., Stieber, A., Lee, E., Wilson, R.B., Trojanowski, J.Q., \& Lee, V. M.-Y. (2008). a-Synuclein-induced aggregation of cytoplasmic vesicles in Saccharomyces cerevisiae. Molecular Biology of the Cell, 19(3), 1093-1103.

Crossref • PubMed • PMC • Google Scholar

9. Stasyk, O. (2017). Methylotrophic yeasts as producers of recombinant proteins. In A. Sibirny (Ed.) Biotechnology of Yeasts and Filamentous Fungi (pp. 325-350). Springer, Cham. Crossref $\bullet$ Google Scholar

10. Stasyk, O., Romanyshyn, A., Denega, I., Klymyshyn, N., \& Stasyk, O. (2016). Influence of different concentrations of extracellular glucose on cytotoxicity of human $\alpha$-synuclein in model strains of the yeast Hansenula polymorpha. Visnyk of the Lviv University. Series Biology, 73, 85-95. [In Ukrainian]

Google Scholar

11. Tenreiro, S., Franssens, V., Winderickx, J., \& Outeiro, T.F. (2017). Yeast models of Parkinson's disease-associated molecular pathologies. Current Opinion in Genetics \& Development, 44, 74-83.

Crossref $\bullet$ PubMed $\bullet$ Google Scholar

12. Tenreiro, S., Reimão-Pinto, M.M., Antas, P., Rino, J., Wawrzycka, D., Macedo, D., RosadoRamos, R., Amen, T., Waiss, M., Magalhães, F., Gomes, A., Santos, C. N., Kaganovich, D., \& Outeiro, T. F. (2014). Phosphorylation modulates clearance of alpha-synuclein inclusions in a yeast model of Parkinson's disease. PLoS Genetics, 10(5), e1004302.

Crossref $\bullet$ PubMed $\bullet$ PMC $\bullet$ Google Scholar

13. Winston, F., Dollard, C., \& Ricupero-Hovasse, S. L. (1995). Construction of a set of convenient Saccharomyces cerevisiae strains that are isogenic to S288C. Yeast, 11(1), 53-55.

Crossref • PubMed • Google Scholar

14. Witt, S.N., \& Flower, T.R. (2006). a-Synuclein, oxidative stress and apoptosis from the perspective of a yeast model of Parkinson's disease. FEMS Yeast Research, 6(8), 1107-1116. Crossref $\bullet$ PubMed $\bullet$ Google Scholar 


\title{
КОНСТРУЮВАННЯ МОДЕЛЬНОГО ШТАМУ ДРІЖДЖІВ SACCHAROMYCES CEREVISIAE 3 РЕГУЛЬОВАНОЮ ЕКСПРЕСІЄЮ АЛЬФА-СИНУКЛЕЇНУ ЛЮДИНИ
}

\author{
Н. В. Грушаник', Ю. І. Федорко ${ }^{1}$, О. В. Стасик², О. Г. Стасик ${ }^{1,2}$ \\ 1 Львівський національний університет імені Івана Франка \\ вул. Грушевського, 4, Львів 79005, Україна
}

${ }^{2}$ /нститут біології клітини НАН України, вул. Драгоманова, 14/16, Львів 79005, Україна

Вступ. Відомо, що однією з причин хвороби Паркінсона є неправильний фолдинг і накопичення агрегатів $\alpha$-синуклеїну. Найважливішим чинником, що впливає на процес агрегації $\alpha$-синуклеїну, є рівень цього білка в нейронах, який залежить від балансу рівноваги між його синтезом, деградацією та секрецією. За певних умов, коли синтезується велика кількість $\alpha$-синуклеїну, мономери цього білка можуть агрегувати на ліпідній мембрані, що призводить до утворення амілоїдів, фрібрил і протофрібрил, не здатних виконувати фізіологічні фрункції. Оскільки вивчення властивостей $\alpha$-синуклеїну in vivo $€$ неможливим, дослідники активно послуговуються модельними біологічними системами (одноклітинні мікроорганізми, лінії людських клітин, тваринні моделі тощо).

Метою цього дослідження було сконструювати рекомбінантний штам S. cerevisiae з регульованою експресією людського $\alpha$-синуклеїну для дослідження властивостей цього білка в умовах in vivo та скринінгу низькомолекулярних сполук, що впливають на його агрегацію та деградацію.

Матеріали і методи. У цій роботі методом електротрансформації було отримано рекомбінатний штам $S$. cerevisiae з регульованою експресією $\alpha$-синуклеїну, кон'югованого зі зеленим фрлуоресцентним білком. Для виявлення рівня експресії відповідного білка застосовано метод Вестерн-блотингу зі специфічними антитілами, а для дослідження внутрішньоклітинної локалізації - метод фрлуоресцентної мікроскопії.

Результати. Унаслідок експериментальної роботи було сконструйовано рекомбінатний штам S. cerevisiae, в якого кодуюча послідовність гена $\alpha$-синуклеїну людини експресувалася з-під регульованого промотора гена ScMET25. У ході аналізу впливу різних концентрацій екзогенного метіоніну (як фрактора регуляції експресії промотора ScMET25) на вміст рекомбінантного білка у клітинах дріжджів було виявлено, що експресія відповідного химерного гена у модельному штамі репресується за наявності метіоніну в концентрації 10 мг/л та вище. Під час тривалого культивування клітин дріжджів цей ефект зменшувався, імовірно, внаслідок вичерпання метіоніну в ростовому середовищі. Також встановлено, що продукція рекомбінантного $\alpha$-синуклеїну в клітинах $S$. cerevisiae практично не впливала на ріст клітин хазяїна, що вказує на відсутність або незначний токсичний ефект людського $\alpha$-синуклеїну для цього виду дріжджів.

Висновки. Регульована експресія рекомбінантного $\alpha$-синуклеїну в клітинах дріжджів S. cerevisiae може бути використана з метою скринінгу нових сполук, здатних впливати на агрегацію чи деградацію $\alpha$-синуклеїну в клітинах дріжджів.

Ключові слова: Saccharomyces cerevisiae, $\alpha$-синуклеїн, регульована експресія

Received / Одержано 20 August, 2021
Revision / Доопрацьовано 05 September, 2021
Accepted / Прийнято 22 September, 2021
Published / Опубліковано 29 September, 2021

ISSN 1996-4536 (print) • ISSN 2311-0783 (on-line) • Біологічні Студії / Studia Biologica • 2021 • Том 15 / № 3 • C. 41-50 